\title{
The use of vibration monitoring to record the blasting works impact on buildings surrounding open-pit mines
}

\author{
Anna Sołtys ${ }^{1, *}$, Józef Pyra $^{1}$, and Jan Winzer ${ }^{2}$ \\ ${ }^{1}$ AGH University of Science and Technology, Faculty of Mining and Geoengineering, Krakow, \\ Poland \\ ${ }^{2}$ Exploconsult Sp. z o.o., Krakow, Poland
}

\begin{abstract}
Environmental protection law and geological and mining law require the mineral mining plant to protect its surroundings from the effects of mining operations. This also applies to the negative impact of vibrations induced by blasting works on people and construction facilities. Effective protection is only possible if the level of this impact is known, therefore it is necessary to record it. The thesis formulated in this way has been and continues to be the guiding principle of the research works carried out in the AGH Laboratory of Blasting Work and Environmental Protection. As a result of these works are procedures for conducting preventive activities by open-pit mines in order to minimize the impact of blasting on facilities in the surrounding area. An important element of this activity is the monitoring of vibrations in constructions, which is a source of knowledge for excavation supervisors and engineers performing blasting works, thus contributing to raising the awareness of the responsible operation of the mining plant. Developed in the Laboratory of the Mine's Vibration Monitoring Station (KSMD), after several modernizations, it became a fully automated system for monitoring and recording the impact of blasting works on the surrounding environment. Currently, there are 30 measuring devices in 10 open-pit mines, and additional 8 devices are used to provide periodic measurement and recording services for the mines concerned.
\end{abstract}

Keywords: open-pit mining, millisecond blasting, vibration monitoring

\section{Introduction}

Initiating the explosives in long holes is a commonly used method of rock mining, and that is why the related problems are so important for open-pit mining. Only 20 to 30 percent of the detonation energy of explosives is used for mining. The remaining part is lost and it causes scattering of flyrocks, airblast, and seismic waves. Especially the latter ones

*Corresponding author: soltys@agh.edu.pl 
cause a lot of problems because the vibrations of the substrate can affect various building structures in the vicinity of mines. Both mining efficiency and economic aspects lead to the use of as many explosive charges as possible in a single batch, which may, however, cause the increasing problem of harmful impacts.

Long-term research work (also financed by mines) carried out at AGH's Department of Open-pit Mining and activities aimed at disseminating the idea of preventive action in this field in mining plants $[1,2,3]$, allowed on the one hand to develop specific research procedures, and on the other hand to achieve a certain level of awareness among mining supervisors, which results in ongoing consultations, conducting control measurements or even full monitoring of the blasting impact on the environment. This decisively increases the mental comfort of both supervisors and investigators and analysts. Such actions are in most cases socially acceptable.

Generally, the preventive activity of open-pit mines covers two groups of the issue [4]: basic research and recording the level of vibrations in the environment.

The aim of basic research is to determine the conditions for safe execution of blasting works taking into account local geological and mining conditions, as well as the type, quality and technical condition of the surrounding buildings. The final effect of the basic research is to determine the dependencies allowing for the calculation of the allowable mass of explosives for the expected range of excavation within a defined time interval, together with the description of the technique and technology for performing blasting works.

Recording of the blasting work's impact is aimed at checking the validity of the relations specified in the basic research, i.e. the compliance of the intensity level of vibrations induced in the environment with the predicted values together with the assessment of the impact of the recorded vibrations on the buildings. These activities may be performed, as cyclical control measurements or in a wider scope, as vibration monitoring in designated buildings in the vicinity of mining operations.

It results that prevention activities in this respect should include:

- an inventory of the technical condition of the facilities in the surroundings,

- recognition of the directions of vibration propagation and their intensity in the vicinity of the mine excavation, on the basis of which the range of harmful vibration impact and allowable mass of explosives are determined,

- conducting cyclical control measurements,

- vibration monitoring in protected objects in special cases.

The last two points mentioned above are repeatedly cited by experts as recommended for implementation and, in the last period of time, also required by the concession granting authorities as a condition for obtaining it. These are activities resulting from the Environmental Protection Law and the Geological and Mining Law, applicable to enterprises that may have a significant impact on the environment. These include the majority of mines extracting minerals using explosives.

\section{Monitoring of the effects of vibrations on the environment}

Monitoring of vibrations induced by blasting works was the subject of research and projects carried out since 1996 in the Department of Open-pit Mining at AGH [2] and carried out in cooperation with industry. The result of works was the implementation of the measurement, analytical and archiving apparatus into the mining practice. When designing the first measurement system, it was assumed that the measurement of vibrations must be supplemented by an assessment of impact using the Polish standard. This is why the system was equipped with a software, which made it possible to use correction filters complying with the PN-85/B-02170 [5] standard, which made it possible to assess the impact immediately after the measurement. Practically this procedure of system operation is still 
being used, obviously taking into account new analytical and graphical abilities. The cooperation of the AGH's Department with Exploconsult Sp. z o. o. and later also with ASTER s. c. allowed for rapid development of the system to its full automation and adjustment of the impact assessment to the requirements of PN-B-02170:2016-12 [6] standard.

In open-pit mining, the following measuring systems have been used to monitor vibrations induced by blasting works [2]:

- Small Vibration Monitoring Station - Explo 504,

- Vibration Monitoring Mine in 3 versions:

- KSMD with radio communication,

- KSMD GSM with cellular communication,

- KSMD APN with the Internet connection (fig. 1).

The main idea of the changes was to make the system more flexible by:

- direct contact between the measuring station and the central server,

- limitation of the service by the operator,

- the use of the wireless Internet connectivity,

- data is collected on the server and can be accessed at any time without the need to establish a connection to the measuring station.

- remote service maintenance and changes in the software of the measurement device.
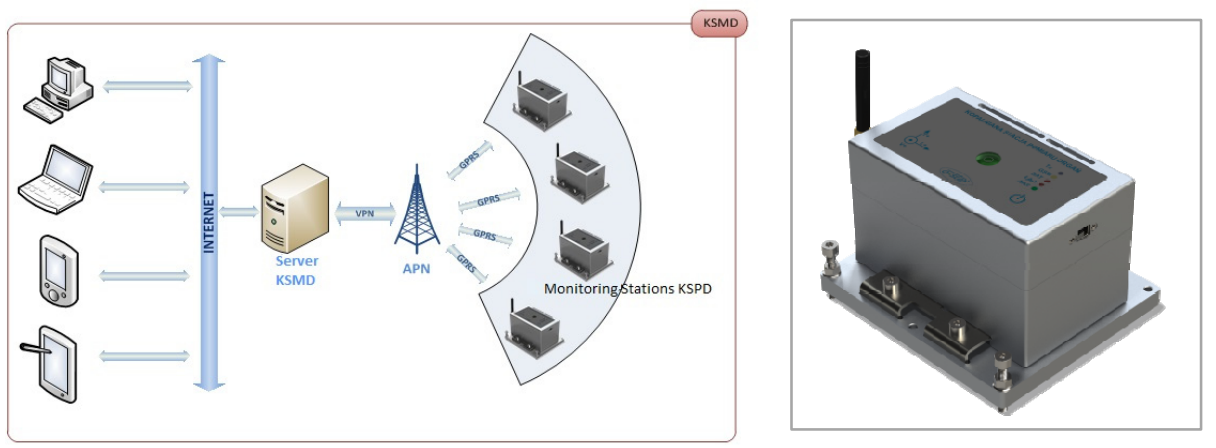

Fig. 1. Mine Station of Vibrations Monitoring - 2012 model.

The basic link of the new system is the KSPD Mine Vibration Measurement Station (fig. 1), equipped with a 3 -axis vibration velocity meter and a number of processing and measurement data collection systems. An integral part of the station is a GSM/GPRS modem that automatically sends the collected measurements to a KSMD server located at AGH, in Krakow.

The web service is used to manage the stations and measurements made by them. It can be used to view measurements, generate reports, manage devices, buildings, and system users. An access to the service is protected by a username and password.

The most important advantage of the modernised system is collecting measurement data on the server - KSPD measuring station, after saving the event in memory, automatically establishes contact and sends the data to the server. In case of communication problems, data transmission shall be repeated until the successful transmission. This is very important because KSPD does not store the data but the KSMD server does. As a result, the system operator cooperates only with the server in terms of analysing or using the database.

Advantages of the new KSMD system:

- continuous vibration measurement in the constructions,

- unlimited memory,

- automatic data transmission to the server,

- constant connection with the server, 
- automation of the station starting process,

- the possibility of contact from any point on the Earth,

- archiving of complete vibration waveforms,

- archiving of reports and impact assessments,

- visualisation of vibration waveforms in time and results on the SWD scale,

- reporting after each event.

Currently, there are 42 measuring points in 13 open-pit mines:

- KSMD APN model - 10 mines and 31 Mining Vibration Measurement Stations (KSPD),

- KSMD GSM model - 2 mines and 11 measurement points.

In addition, AGH Laboratory of Blasting Works and Environment Protection has 2 KSPD stations and Exploconsult company - 7 stations. These stations are periodically rented to perform monitoring in open-pit mines as well as to control the impact of engineering works using explosives (e.g. macro-levelling during the construction of roads, tunneling and demolition works).

\section{Analysis of recording from blasting works}

The operation of the modernised KSMD system started in 2012, therefore the five-year period of operation of the system can be summarised.

In total, all KSMD ANP measurement stations performed 11407 measurements of vibrations induced by blasting works carried out in open-pit mines during last 5 years (2013 to 2017).

Tables 1 and 2 show the number of measurements made by the measurement stations in individual mines until the 31st of December 2017.

Table 1. Vibration measurements made at individual mines - stations owned by mines

\begin{tabular}{|c|c|c|c|c|}
\hline $\begin{array}{c}\text { Mine / raw } \\
\text { material }\end{array}$ & Starting date & $\begin{array}{c}\text { Number of } \\
\text { measuring } \\
\text { points }\end{array}$ & $\begin{array}{c}\text { Number of } \\
\text { measuring } \\
\text { points } \\
\text { (facilities) }\end{array}$ & $\begin{array}{c}\text { Number of } \\
\text { measurements }\end{array}$ \\
\hline Gypsum mine 1 & 05.07 .2012 r. & 4 & 8 & 1491 \\
\hline Limestone mine 1 & 04.07 .2012 r. & 3 & 3 & 1791 \\
\hline Limestone mine 2 & 29.10 .2012 r. & 4 & 5 & 1387 \\
\hline Limestone mine 3 & 25.05 .2013 r. & 4 & 5 & 452 \\
\hline Gypsum mine 2 & 09.04 .2013 r. & 4 & 5 & 1357 \\
\hline dolomite mine 1 & 15.04 .2013 r. & 2 & 5 & 695 \\
\hline Limestone mine 4 & 14.03 .2014 r. & 2 & 3 & 136 \\
\hline Limestone mine 5 & 19.07 .2016 r. & 1 & 1 & 833 \\
\hline dolomite mine 2 & 23.11 .2016 r. & 2 & 2 & 101 \\
\hline shale mine & 24.05 .2015 r. & 2 & 2 & 9764 \\
\hline & In total & & & \\
\hline
\end{tabular}


In all cases KSPD measuring stations are fixed to building foundations at ground level, i.e. the vibration measurement concerns a building and not the ground in its surroundings. This is important information, as the standards of other countries set specific but different requirements in this respect. For example, in Poland, the Mining Rocks of Intensity require the measurement of ground vibrations.

Table 2. Vibration measurements made at individual mines - measurements carried out as a part of the service

\begin{tabular}{|c|c|c|c|c|}
\hline $\begin{array}{c}\text { Mine / raw } \\
\text { material }\end{array}$ & Operation period & $\begin{array}{c}\text { Number of } \\
\text { measuring } \\
\text { points }\end{array}$ & $\begin{array}{c}\text { Number of } \\
\text { measuring } \\
\text { points } \\
\text { (facilities) }\end{array}$ & $\begin{array}{c}\text { Number of } \\
\text { measuremen } \\
\text { ts }\end{array}$ \\
\hline dolomite mine 3 & since $04.08 .2015-$ & 1 & 7 & 160 \\
\hline Limestone mine 6 & since 23.08.2016 & 4 & 4 & 1233 \\
\hline granite mine & 15.05 .2015 to 31.07 .2015 & 1 & 1 & 24 \\
\hline dolomite mine 4 & 02.09 .15 to 10.02 .16 & 1 & 1 & 52 \\
\hline basalt mine & 25.05 .16 to 26.06 .17 & 1 & 2 & 44 \\
\hline ampibolite mine & 16.08 .16 to 23.03 .17 & 2 & 1 & 86 \\
\hline Limestone mine 7 & 03.11 .16 to 22.02 .17 & 1 & 1 & 14 \\
\hline dolomite mine 5 & 09.06 .17 to 30.06 .17 & 1 & & 1643 \\
\hline \multicolumn{2}{|c|}{ In total }
\end{tabular}

For example, the results of measurements obtained by the station - limestone mine 2 / station 1 were analysed in details. Table 3 presents the part of recording results for the 1 quarter of 2013. This part was selected for recording, on January the 17th, the events with the highest intensity during 5 years of station operation.

Table 3. Results of vibration recording in the first quarter of 2013 - limestone mine - station No. 1

\begin{tabular}{|c|c|c|c|c|c|c|c|}
\hline \multirow{2}{*}{ Date } & \multirow{2}{*}{ Time } & \multicolumn{3}{|c|}{ Vibration velocity, mm/s } & \multicolumn{3}{|c|}{ Frequency, Hz } \\
\cline { 3 - 8 } & & $\mathbf{u}_{\mathbf{z}}$ & $\mathbf{u}_{\mathbf{x}}$ & $\mathbf{u}_{\mathbf{y}}$ & $\mathbf{f}_{\mathbf{z}}$ & $\mathbf{f}_{\mathbf{x}}$ & $\mathbf{f}_{\mathbf{y}}$ \\
\hline $2013-01-09$ & $13: 25: 22$ & 0,71 & 1,15 & 0,98 & 11,0 & 9,6 & 11,6 \\
\hline $\mathbf{2 0 1 3 - 0 1 - 1 7}$ & $\mathbf{1 3 : 2 0 : 3 7}$ & $\mathbf{1 , 5 2}$ & $\mathbf{2 , 6 4}$ & $\mathbf{5 , 2 0}$ & $\mathbf{1 2 , 6}$ & $\mathbf{1 1 , 4}$ & $\mathbf{1 1 , 0}$ \\
\hline $2013-01-17$ & $13: 23: 05$ & 1,24 & 2,64 & 2,20 & 13,0 & 12,0 & 11,6 \\
\hline $2013-02-14$ & $13: 21: 44$ & 2,08 & 3,43 & 2,44 & 17,0 & 16,7 & 11,3 \\
\hline
\end{tabular}

The figure 2 presents the visualization of recordings on the SWD-I scale (horizontal components $\mathrm{x}$ and $\mathrm{y}$ ), and the percentage distribution of maximal velocities within the assumed value ranges.

The visualization of the measurement results is shown on two graphs, as the maximum value of the vibration velocity (without frequency) does not give full information about the impact, due to the shape of the SWD limit lines. At the same time, it is important to be 
aware that the measurement results, in the form of maximum values of frequency correlated with vibration velocities, applied on the SWD scale do not constitute an impact assessment, but only illustrate the scale of the problem and allow for the preliminary conclusions to be drawn as to the level of recorded vibrations over a longer period of time.

When analysing the data presented in Figure 2, it should be noted that almost $85 \%$ of the vibrations induced by the blasting works did not exceed a maximum value of 1.33 $\mathrm{mm} / \mathrm{s}$, which means that they can be classified as negligible in the process of impact assessment for a protected object [6].

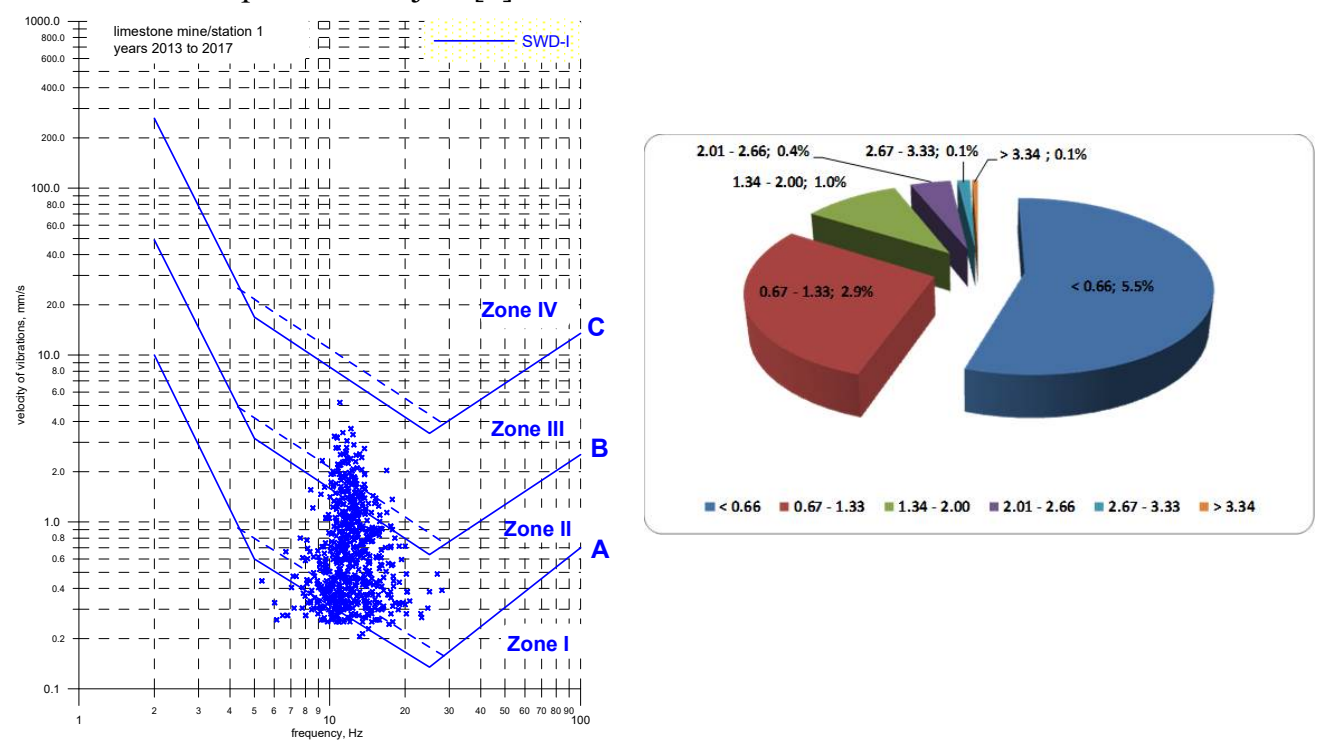

Fig. 2. Visualization of vibration recording results for the years 2013 to 2017.

As already mentioned, on 17 January 2013, the event with the highest intensity during the five-year period was recorded. For example, the structure of these vibrations are shown in Figures 3. As shown in Figure 3, the $12.59 \mathrm{~Hz}$ frequency is predominant in the structure of vibration and the horizontal component $y$ is predominant in the impact assessment, as shown in Figure 4.

The assessment of induced vibrations impact, in accordance with the procedure in the standard [5] (fig. 4), has shown that these vibrations should be classified as zone III of the SWD-I scale. It should be noted here that it is a single event recorded over a period of 5 years, and only $0.6 \%$ of the recording (4 events out of 692 ) exceeded the value of $3.33 \mathrm{~mm} / \mathrm{s}$. 


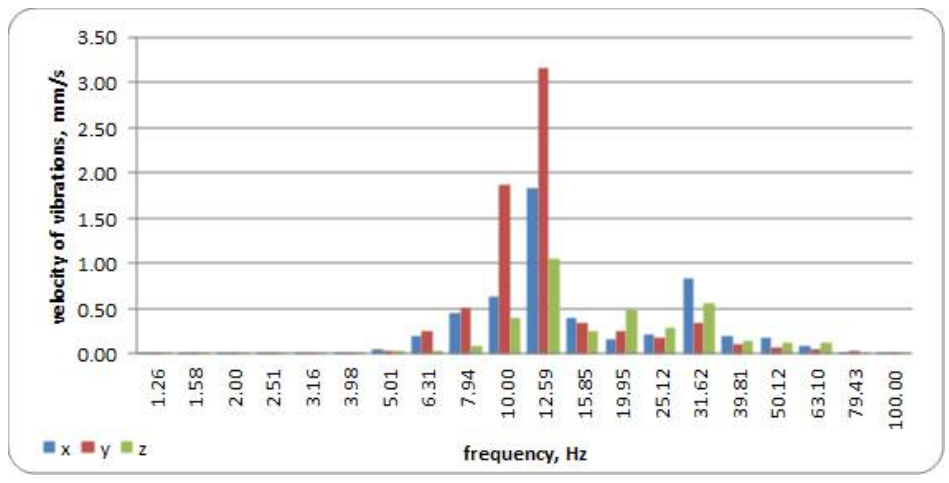

Fig. 3. The structure of vibrations registered on 17.01.2013 - limestone mine / station 1 .

The number of performed measurements and the scope of measured values are the information of the essential significance during every compensation proceeding. The fact that most events are recorded by vibration measurements, each of which can be used as a basis for assessing the impact on the building, and most importantly, only a few (of the highest intensity) of the hundreds of documented events were perceived vibrations, is very important for the opinion formers, and consequently also for the courts.

a)

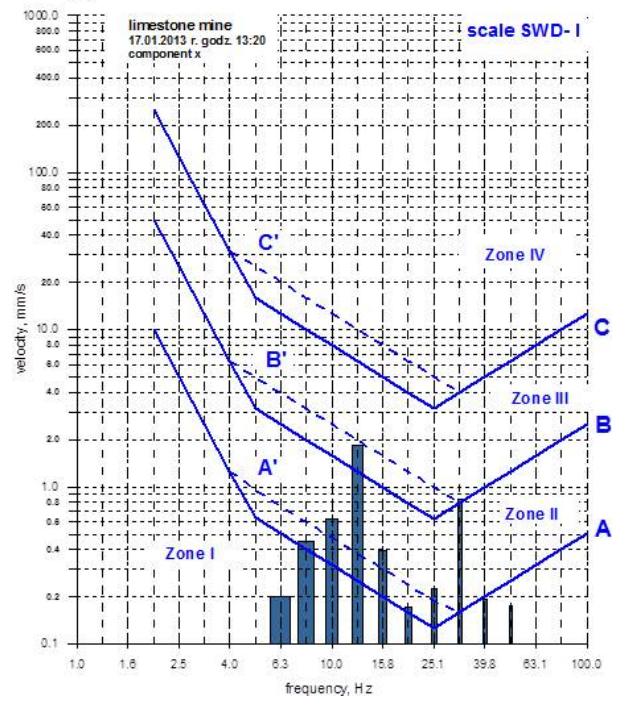

b)

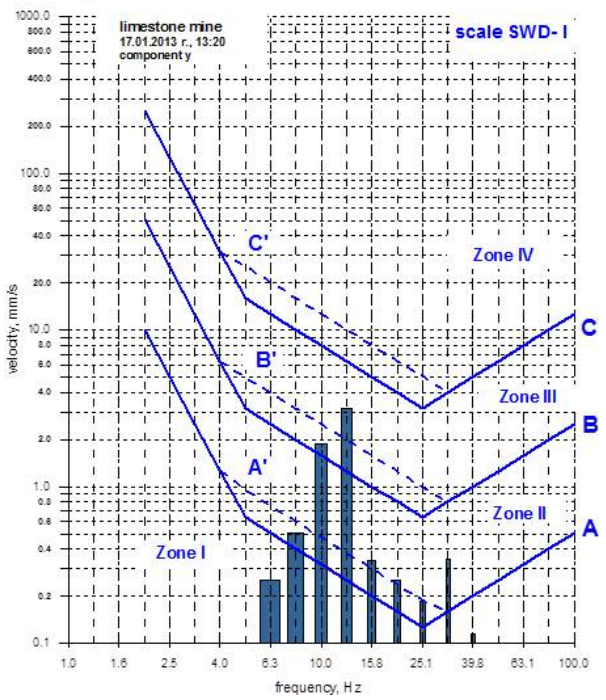

Fig. 4. Vibration impact assessment - limestone mine/station 1 - event dated of the 17 th of January 2013: a) component $x, b$ ) component $y$

On the basis of observations made during the monitoring, despite the occurrence of recorded vibrations which were qualified to the third zone of the SWD scale, no new damages or deepening of already existing cracks in the building structure has been observed. It has to be emphasized that this was the only event qualified to the third zone, out of 692 recorded within 5 years window. It can, therefore, be concluded that the occurrence of individual events qualifying to the third zone of the SWD scale does not contribute to the occurrence of new damages in the protected site. 


\section{Summary}

Monitoring of vibrations induced by blasting works on constructions, in the vicinity of the excavation, is an important element of the prophylactic activity of open-pit mines in the scope of minimizing the impact of exploitation works on the environment.

Documenting the impact of blasting works on the environment is a solution that allows to:

- collect up-to-date information for surveillance, concerning the intensity of vibrations induced by blasting works,

- monitor the impact of vibrations on building structures,

- create a database, which can always be used to provide evidence of damages,

- make current corrections under conditions limiting the performance of blasting works.

The KSMD system used in mining plants, which was built with the financial participation of open-pit mines, has been gradually modernized, thanks to which it is now a modern, automated system which uses new technologies in the field of measurement, analysis and wireless communication. The system has been created as a tool for supervising personnel, enabling the current control of the blasting works impact on buildings in the surrounding area.

After the modernization, KSMD enables access to measuring devices from any point on the ground, control of measuring equipment, an immediate preview of the recorded event and rapid impact assessment.

In vibration monitoring nothing is accidental. The permanent presence of measuring equipment in the protected object allows for recording also events not related to blasting works. Sometimes shocks caused by underground mines are recorded, as well as vibrations induced by blasting works in neighbouring open-pit mines.

The operation of vibration monitoring systems provides thousands of evidence that controlled blasting works in open-pit mines can be harmless to buildings in the surrounding environment.

\section{References}

1. E. Maciąg, J. Winzer, R. Biessikirski, Metodyka postępowania w ochronie otoczenia w przypadku robót strzałowych. Bezpieczeństwo Pracy i Ochrona Środowiska w Górnictwie 9(157)/I/2007, pp. 56 - 60 (2007)

2. J. Winzer, Dokumentowanie oddziaływania robót strzałowych na otoczenie kopalń odkrywkowych. Górnictwo Odkrywkowe, R. 48, nr 3-4/2006, pp. 159-167 (2006)

3. J. Winzer, A. Sołtys, J. Pyra, Oddziaływanie na otoczenie robót z użyciem materiałów wybuchowych. (Wydawnictwa AGH, Kraków, 2016)

4. J. Pyra, A. Sołtys, J. Winzer, Skomputeryzowane systemy do dokumentowania oddziaływania robót strzałowych na otoczenie kopalń odkrywkowych. Bezpieczeństwo Robót Strzałowych, GIG, pp. 79 - 88 (2012)

5. PN-B-02170:1985 - Ocena szkodliwości drgań przekazywanych przez podłoże na budynki.

6. PN-B-02170:2016-12 - Ocena szkodliwości drgań przekazywanych przez podłoże na budynki. 